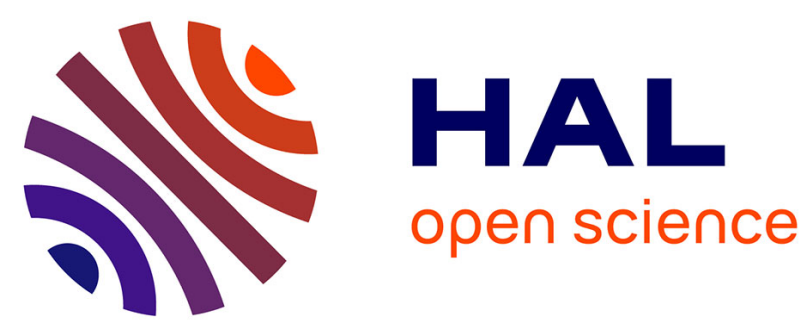

\title{
Are 5G Networks and the Neutral Host Model the Solution to the Shrinking Telecom Market
}

Ioannis Neokosmidis, Theodoros Rokkas, Dimitris Xydias, Antonino Albanese, Muhammad Shuaib Siddiqui, Carlos Colman-Meixner, Dimitra Simeonidou

\section{- To cite this version:}

Ioannis Neokosmidis, Theodoros Rokkas, Dimitris Xydias, Antonino Albanese, Muhammad Shuaib Siddiqui, et al.. Are 5G Networks and the Neutral Host Model the Solution to the Shrinking Telecom Market. 14th IFIP International Conference on Artificial Intelligence Applications and Innovations (AIAI), May 2018, Rhodes, Greece. pp.70-77, 10.1007/978-3-319-92016-0_7 . hal-01821301

\section{HAL Id: hal-01821301 \\ https://hal.inria.fr/hal-01821301}

Submitted on 22 Jun 2018

HAL is a multi-disciplinary open access archive for the deposit and dissemination of scientific research documents, whether they are published or not. The documents may come from teaching and research institutions in France or abroad, or from public or private research centers.
L'archive ouverte pluridisciplinaire HAL, est destinée au dépôt et à la diffusion de documents scientifiques de niveau recherche, publiés ou non, émanant des établissements d'enseignement et de recherche français ou étrangers, des laboratoires publics ou privés. 


\title{
Are 5G Networks and the Neutral Host Model the Solution to the Shrinking Telecom Market
}

\author{
Ioannis NEOKOSMIDIS ${ }^{1}$, Theodoros ROKKAS ${ }^{1}$, Dimitris XYDIAS ${ }^{1}$, Antonino \\ ALBANESE $^{2}$, Muhammad Shuaib SIDDIQUI ${ }^{3}$, Carlos COLMAN-MEIXNER ${ }^{4}$ and \\ Dimitra SIMEONIDOU ${ }^{4}$ \\ ${ }^{1}$ inCITES Consulting SARL, Strassen, Luxembourg \\ ${ }^{2}$ ITALTEL, Castelletto, Milan, Italy \\ ${ }^{3}$ Fundacio i2CAT, Software Networks Area, Barcelona, Spain \\ ${ }^{4}$ High Performance Networks Group, University of Bristol, United Kingdom \\ i.neokosmidis@incites.eu
}

\begin{abstract}
G networks will offer advanced functionalities and features such as high throughput, low latency, security and reliability by leveraging technological advances like network virtualization, edge computing and network slicing. The latter will facilitate the entrance of new players in the value chain. Moreover, they will offer a means for network operators to change their business models in order to address revenue losses. The concept of a neutral host supported by the H2020 5GCity project seems to be a strong candidate for future business models helping network operators thrive in the new telecom era.
\end{abstract}

Keywords: $5 \mathrm{G}$ networks, business model, cloud computing, neutral host, NFV, $\mathrm{SDN}$, telecom market.

\section{$1 \quad$ Introduction}

During the last decade, European telecom operators have been experiencing declines in their revenues, mainly because service prices stagnation, regulations, and an increasing demand of investments in their infrastructures. As a result, operators have been looking for innovative ways to turnaround this negative situation by considering the adoption of 5G networks given their technological, economical, and social values [1].

The 5G-PPP association has identified a series of specifications and KPIs [2] for 5G networks to be addressed by several ongoing initiatives and projects. The $5 \mathrm{G}$ networks KPIs are ultra-high data rates, low latency, reliability and, host neutrality. The last KPI will give a very important role to $5 \mathrm{G}$ technology in enabling new players from the vertical industries to enter the digital value chain, something that has not been done yet with the currently available technologies. This role will create significant social value through cutting-edge technological applications in various industries, such as medical care, transportation, and entertainment.

Hence, 5G networks are expected to offer new business opportunities and business models like neutral host to existing network operators. This can be attributed to the fact 
that 5G networks will make use of technological advances in network function virtualization [3], software-defined networks (SDN) [4], edge computing, end-to-end network slicing and network analytics. Such innovative technologies will improve network performance and facilitate the development of sliceable applications and services.

This paper aims to investigate the neutral host business model, as proposed in the 5 GCity project, along with the necessary changes that network operators need to make in their business models to thrive in the new digital era. The obtained results will be a valuable tool for decision makers, so to achieve the maximum exploitation of the technological advances of $5 \mathrm{G}$ and accelerate the return of network operators to revenue growth.

The objective of 5GCity [5], an innovation project financed within the 5G PublicPrivate Partnership (5GPPP) initiative by the European Commission (Horizon 2020 program), is the design, development, deployment and demonstration of a distributed cloud and radio platform for municipalities and infrastructure owners acting as $5 \mathrm{G}$ neutral hosts. The project's aim is to build and deploy a common, multi-tenant, open platform that extends the (centralized) cloud model to the extreme edge of the network, with demonstrations in three different cities (Barcelona, Bristol and Lucca). 5GCity will directly impact a large and varied range of actors: (i) telecom providers; (ii) municipalities; and (iii) several different vertical sectors utilizing the city infrastructure.

The rest of the paper is organized as follows: Section 2 presents the status of today's telecom market. Section 3 introduces the expected future of telecom networks along with the involved actors. Section 4 describes the required changes for network operators to increase their revenue. Section 5 introduces the role of a neutral host in a 5G Small Cell network. Finally, section 6 concludes this work.

\section{Status of Today's Telecom Market}

The impact of the financial crisis of 2008 has different repercussions in EU based on each country's economic structure. As expected, southern European countries were strongly influenced by this crisis. While the growth of GDP in Greece remains negative, Italy and Spain have recovered the growth last year.

However, ICT networks provide the backbone for digital products and services that have the potential to support all aspects of our lives, and drive Europe's economic recovery [6]. Well-functioning markets deliver access to high-performance fixed and wireless broadband infrastructure, at affordable prices. Successive adaptations of the EU's telecoms rules combined with the application of EU competition rules, have been instrumental in ensuring that markets operate more competitively, bringing lower prices and better quality of service to consumers and businesses. Effective competition is a key driver for investment in telecoms networks.

Electronic communications sector represented 2,1\% of EU's GDP in 2014, compared to 2,3\% in 2013 and 2,7\% in 2009. In 2014 the revenues of the electronic communications sector in the European Union were estimated at 300 billion euros while investment was about $\sim 12 \%$ of the total turnover (Figure 1). 


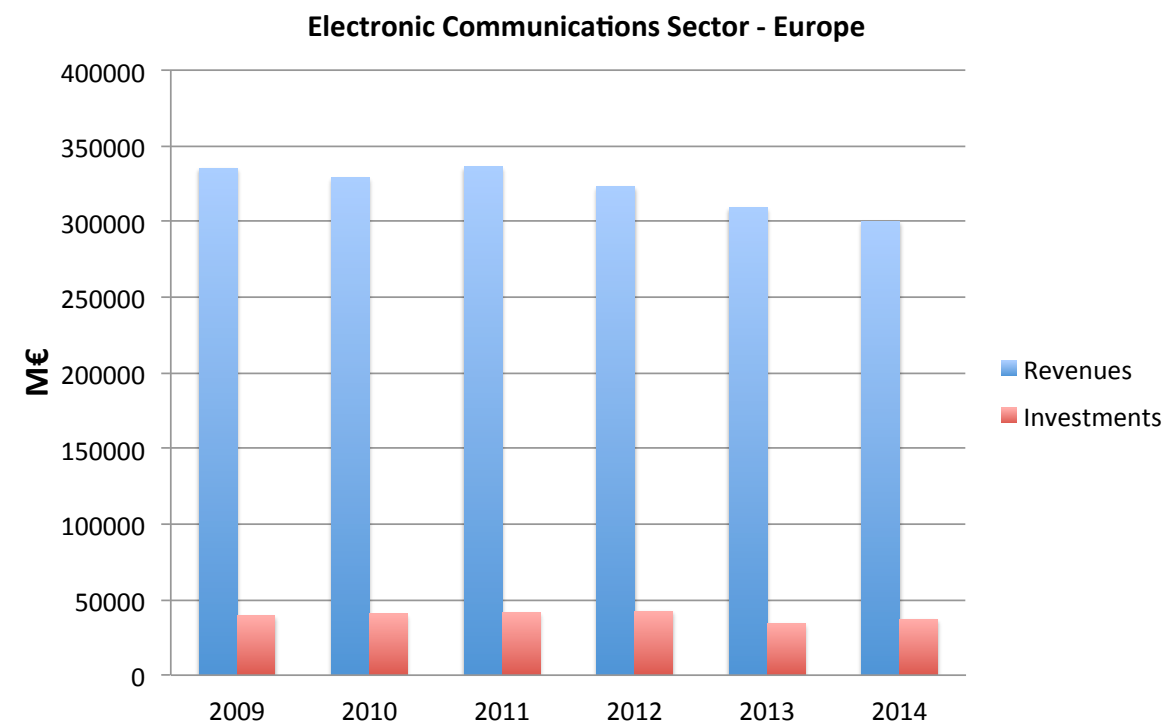

Fig. 1. Electronic Communications Sector Revenues and Investments (source: Digital Agenda Scoreboard)

According to inCITES Consulting connectivity database, Prognosis, both mobile and fixed service revenues were in decline in Western Europe for nearly a decade till 2016 (figure 2).

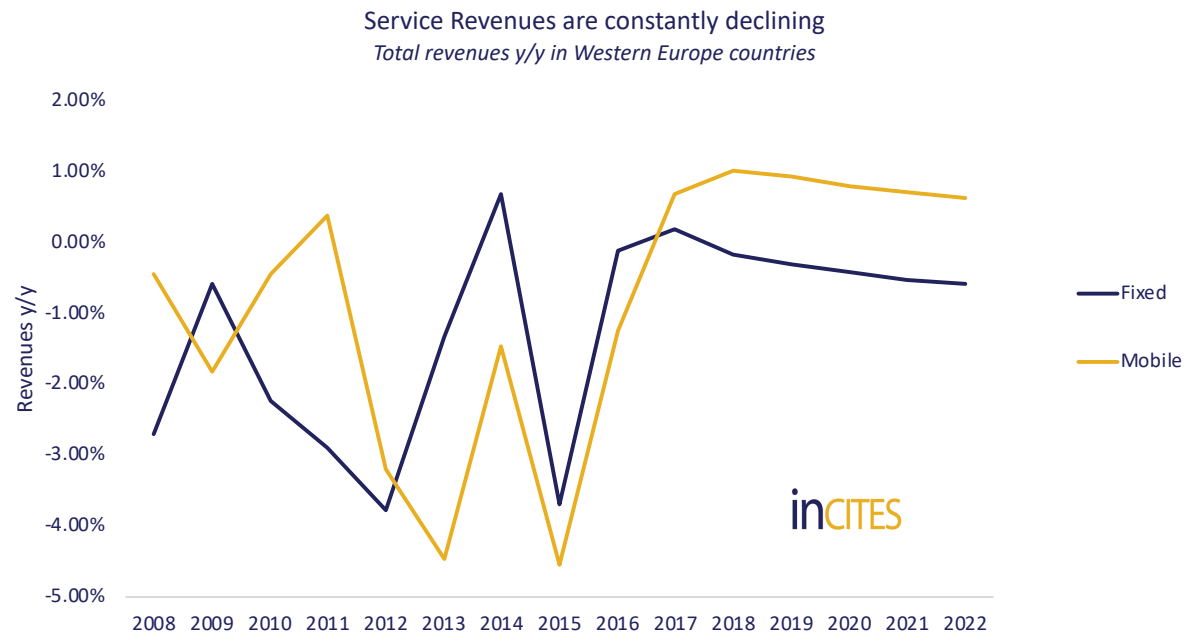

Fig. 2. Year-on-year service revenue trend for fixed and mobile markets in Western Europe (source: inCITES Consulting) 
This can be attributed to the mobile termination rate cuts and other regulatory interventions (e.g. EU Zero Roaming) leading to ARPU squeeze as well as to the proliferation of bundles and decrease of voice traffic. Figure 3 illustrates the average revenue per user in the retail mobile market.

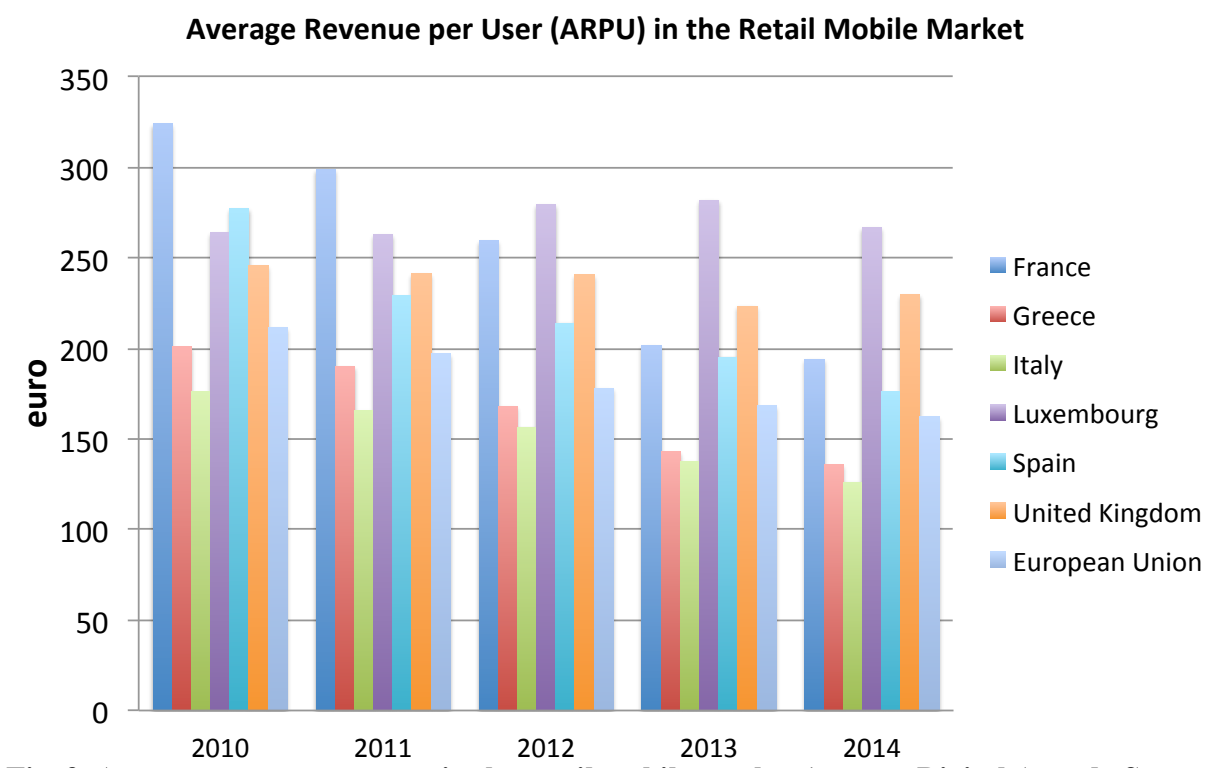

Fig. 3. Average revenue per user in the retail mobile market (source: Digital Agenda Scoreboard)

inCITES forecasts the service revenues to grow at a $0.8 \%$ CAGR in the mobile case and to drop at a $-0.3 \%$ CAGR in the fixed case between 2017-22. It is evident that the forecasted increase in revenues is very small if one takes into account the ongoing growth in data traffic. According to Cisco Visual Networking Index (VNI), the global mobile data traffic grew an estimated 74 percent in 2015. Growth rates varied widely by region, with Central and Eastern Europe at $71 \%$ followed by Western Europe (52\% in 2015). In 2015 mobile data traffic was 545.750 and 432.322 Terabytes per month in Central \& Eastern Europe and Western Europe respectively (Statista).

\section{The Future of Telecom Networks - Involved Actors}

The value creation in the telecommunications market is no longer the case of a closed market limited to few players: new roles and relationships are evolved and become part of the new ecosystem. Each actor must understand its position to increase its value and maximize the potential revenues. 
The following section describes the initial insights regarding the value chain analysis for future $5 \mathrm{G}$ networks. The involved actors and their relative position in the value chain is depicted in Figure 4.

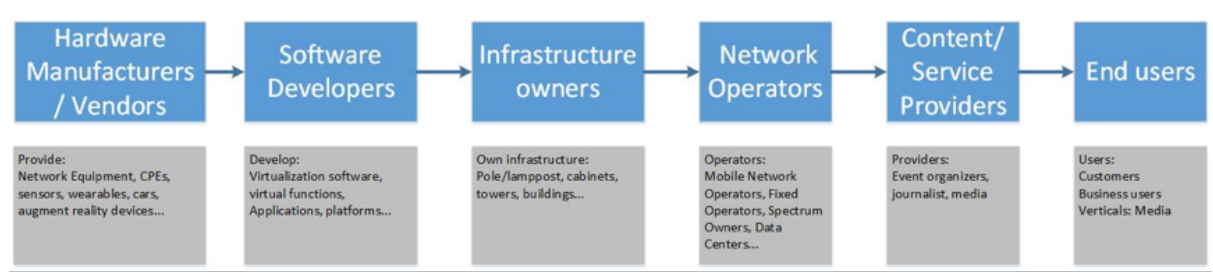

Fig. 4. Value chain analysis

\section{Hardware (Equipment) manufacturers / vendors}

This actor is on the beginning of the value chain and provides all the necessary equipment to all other involved. It includes entities that either manufactures and/or sells equipment. This equipment can be ICT related like servers, hard disk drives, RAM etc., networking equipment like routers and switches and radio equipment like small cells. In a broader perspective, we can also include vendors that manufacture equipment associated with the city infrastructure such as lampposts, cabinets, cameras, sensors etc. It also includes vendors providing devices for End Users such as mobile phones, tablets and wearable devices that allow the delivery of enhanced $5 \mathrm{G}$ services like augmented reality or UHD video.

\section{Software Developers}

These entities develop the necessary software as well as the Virtual Network Functions (VNFs) for the delivery / provision of $5 \mathrm{G}$ services. The VNFs can be classified as i) those that are necessary for the delivery of the service and ii) those that are complementary and are tailored to fulfil the requirements of users like the media vertical or immersive services. This type of actor also includes entities who develop applications, like for example video analytics or augmented reality software.

\section{Infrastructure owners}

These entities own the necessary infrastructure that can be used for hosting the computing, storage and networking infrastructure. The available resources include space in street cabinets, lampposts or buildings along with power supply and connectivity facilities. These are necessary to power and interconnect the ICT equipment. Municipalities can be included in this category and are expected to play a significant role since they possess both facilities and ICT infrastructure. Municipalities will act as a Neutral Host providing wholesale access to interested parties (network operators). Thus, such entities will be of high importance since they enable network densification and keeping low costs.

\section{Network Operators (ICT infrastructure providers)}


This category includes all types of network operators like mobile and fixed, cloud providers, data centers that owns the physical resources of the network. It also includes entities that own spectrum licenses. This entity will receive wholesale access from Neutral Host in order to provide services to end-users.

\section{Content/Service Providers}

It includes entities that does not own network resources but use virtual resources to create and provide their own services. By taking advantage of the Neutral Host concept, service providers have a pool of different type of resources that can select and use to develop new and innovative services. The type of services they offer can be connectivity, Internet access, content distribution etc. They can develop their own content or come into agreement with other Content Providers or even End Users. They enter into Service Level Agreements with Network Operators to get access to the physical resources.

\section{End Users}

This term covers all short of users that range from simple users that seek only connectivity services to vertical industries that have more specific and tight requirements. They are the ultimate consumers of the services created in the telecommunication ecosystem. Furthermore, End Users can become content producers to Service Providers.

\section{$4 \quad$ Mandatory Changes in Operators' Business Models}

In this section, the necessary changes that will allow network operators to thrive in the new digital era are investigated and presented.

\subsection{Network operators to exploit their strong position as network owners}

In the last years, network operators have seen OTTs and vendors gaining a big part of end-user relationships. Taking also into account that connectivity is no longer profitable, network operators are seeking a role as intermediates between vendors and OTTs facilitating partnerships and adopting a wholesale and a "smart pipe" model towards success. In the so-called neutral host model, OTTs, virtual operators and third parties are leasing access from network operators in order to provide their services while vendors are attracted by operators' large scale. Moreover, manufacturers and vendors will be able to connect their devices in the new Internet of Things era. Network operators should resort to recent technologies such as network analytics, software defined networks and network virtualization to optimize network operation and improve its performance. By leveraging cloud computing, networks operators are aiming to a digital single market where they can provide their services remotely from any part of the value chain leading to significant savings due to economies of scale. 


\subsection{Networks operators to get closer to clients' needs}

Networks operators should leverage recent technological achievements in order to provide tailor-made personalized services to their customers. Networks operators are probably the only entity that is able to securely collect and analyze users' data. Using big data analytics, valuable knowledge can be extracted enabling them to adapt their products and investment plans in order to meet B2B and B2C requirements. Using advanced computing capabilities, networks operators can now adopt different (e.g. per usage) and / or hybrid pricing schemes and offer customer and price differentiation.

\subsection{Required Investments}

In order to stay on top of technological advances and achieve the aforementioned transformations, networks operators should also change their investment strategies. On the one hand, networks operators should definitely continue investing in infrastructure in order to expand their networks. Since this is a capital-intensive process, networks operators should resort to alternative funding schemes (e.g. network sharing and coinvestments) and exploit governmental subsidies and PPPs. On the other hand, network investments should be accompanied by software-based investments which are essential for controlling and maintaining the network.

\section{The role of Neutral host in 5 G networks - Potential Risks}

In future 5G network deployments, Small Cells [7]-[9] are expected to play a significant role in reaching the KPIs as these are specified from 5G-PPP. However, Small Cells deployment usually requires locations with costly backhaul and power facilities, which might hinder the mass deployment of Small Cells. In addition, it should be highlighted that the deployment of "parallel" access networks will be prohibited especially in dense areas. Within future 5G infrastructures, network sharing should evolve beyond the traditional infrastructure sharing models used in previous generations, i.e. site, mast, RAN and core network sharing, towards cloudification, virtualization and holistic end-to-end network slicing.

Given this complex landscape, the business model of a neutral operator owning the infrastructure and providing wholesale access to mobile operators seems to be among the most promising ones. For example, a neutral host operator (i.e., the infrastructure owner) could deploy and manage Small Cells while leasing out slices of network capacity to the different $5 \mathrm{G}$ service providers on an equal basis to foster competition. However, the advantages of a neutral host operator model are accompanied by several risks related to the possibility of a monopolistic behavior. This contains the risk for abuse of dominant position. In such case, the neutral host operator may refuse to supply the necessary wholesale input, to proceed to excessive pricing as well as to demonstrate discrimination among operators/customers and / or set barriers to new entrants. In order to address these challenges, careful monitoring mechanisms are necessary. These will ensure the public/general interest as well as maximization of the social welfare. NRAs, NCAs, State Aid/PPP are authorities that can potentially undertake the monitoring 
processes with the first being the most appropriate due to its expertise on remedies such as price cap regulation, retail minus regulation, etc. that require cost accounting models and relative experience.

\section{Conclusions}

European telecom companies faced reductions in their revenue associated to variety of factors. 5G networks through a neutral host business model promises to revive opportunities for telecom operators to increase their revenue and new social and economic values for the society.

In this paper, we investigated the necessary changes that should be adopted by network operators to remain competitive by first reporting the status of the telecom market in decreasing revenues fashion. Then we describe the role of telecom networks and actors in the new digital. Followed by several guidelines that will be useful for network operators to adequate their business model by including the neutral host model supported by the H2020 5GCity project. Finally, we described the role of neutral host to address the deployment limitations of $5 \mathrm{G}$ networks along with their potential risks.

\section{$7 \quad$ Acknowledgment}

The research leading to these results has been supported by the EU funded H2020 5GPPP project 5GCity (grant agreement No. 761508).

\section{References}

1. G. W. Report, "Identification and quantification of key socio-economic data for the Strategic Planning of 5G introduction in Europe," SMART 2014/0008, 2015

2. https://5g-ppp.eu/kpis/

3. N. M. Mosharaf, K. Chowdhury and R. Boutaba, "A Survey of Network Virtualization," Computer Networks, Vol. 54, No. 5, pp.862-876, 2010

4. B.A.A. Nunes, M. Mendonça, X.-N. Ngyen, K. Obraczka and T. Turletti, "A Survey of Software-Defined Networking: Past, Present, and Future of Programmable Networks," IEEE Communications Surveys and Tutorials, Vol. 16, No. 3, pp.1-18, 2014.

5. www.5gcity.eu

6. European Commission (2015): Communication from the European Commission on "A Digital Single Market Strategy for Europe" [COM(2015) 192 final, 06.05.2015]. Available at:

7. Small Cell Forum (SCF) Release 7.0: Document 055.07.01 - Small Cells and 5G Evolution: A Topic brief. Available at: http://scf.io/en/documents/055_Small_cells_and_5G_evolution_a_topic_brief.php.

8. T Q. S. Quek, G. de la Roche, İ. Güvenç, M. Kountouris, "Small Cell Networks Deployment, PHY Techniques, and Resource Management", Cambridge University Press, 2013

9. H. A. Mahmoud and I. Guvenc, "A comparative study of different deployment modes for femtocell networks," in Proc. IEEE Indoor Outdoor Femtocells (IOFC)Workshop (co-located with PIMRC 2009), Tokyo, Japan, Sep. 2009, pp. 1-5. 